\title{
Effect of Rumen-Inert Fat Enriched with High Levels of Poly-Unsaturated Fatty Acids on the Productive and Reproductive Response in Ruminants
}

\author{
Alejandro Salvador, Rolando Hernandez, Thais Diaz and Ricardo Betancourt
}

Additional information is available at the end of the chapter

http://dx.doi.org/10.5772/50879

\section{Introduction}

The chapter will discuss the effect of rumen-inert fat enriched with high levels of polyunsaturated fatty acids (PUFA) on the productive and reproductive responses in ruminants. The discussion will include characteristics of the milk and its derivatives such as goat cheese. The expertise presented in the chapter will cover the authors' experience about the interrelationship between nutrition and reproduction in ruminants from the College of Veterinary Sciences at the Central University of Venezuela.

The success of milk and meat production systems with ruminants depends largely on an efficient reproductive performance of the herd. Thus, numerous researchers have tried to identify the different factors affecting the productive and reproductive behavior of these herds, being the nutritional component one of the factors that has the highest impact on tropical livestock. Marked shortcomings of forage quality and quantity generate undernourished animals, originating low production parameters in our livestock, far below the desired levels. In countries located in the tropical region of the world the reproductive efficiency in beef and dairy cattle is low, no more than 40-45\% (Diaz, 2009). In addition, the pregnancy rate in first calf cows is around $30 \%$, post-partum anestrous period for cattle ranges from 150 to 210 days (Montaño and Ruiz, 2005) and early embryonic mortality in lactating dairy cows, is around $30 \%$ (Bach, 2003).

Furthermore, during the early postpartum period the lactating cow (dairy, beef and dual purpose cows), as well as the dairy goats, show a gap between the consumption and the amount of energy needed, especially during the time of maximum requirements, when the cow and the goat do not meet their nutritional requirements, which leads to the massive 
mobilization of its body reserves, particularly energy, generating a state known as the Negative Energy Balance (NEB), which can cause deleterious effects on milk production, health and reproductive performance.

A practical way to control this NEB is through the increase of the food consumption by animals and/or the increase of the energy density of the diet. Thus, various food technologies have been developed for this purpose: energy banks, the use of strategic crops such as sugar cane, liquid diets with high levels of energy, multi-nutritional blocks and energy supplementation with rumen-inert fat. Increasing the fat content of the ration is a way to decrease the NEB, because of fats have double the energy than sugars. However, there are limitations on their use, particularly if the fat is not a rumen-inert fat.

If rumen-inert fat is used to feed ruminants, some undesirable effects of active fats at ruminal level, would be avoided, and higher amount of fat could be used.

On the other hand, if the fat is rich in polyunsaturated faty acids (PUFA; linoleic, linolenic, docosahexanoic [DHA], or eicosapentaenoic acid [EPA]), the rumen-inert fat enriched not only supplies energy, but allows the incorporation of the beneficial effects that these fatty acids have on the animal body and in the productive and reproductive response, therefore having a nutraceutical effect, i.e., producing meat and milk with high levels of these fatty acids, which may have a beneficial effect on human health.

\section{The fat and the feeding of ruminants}

Fats are important in ruminant nutrition because of its high energy content. In this regard, the complete combustion of one gram of fat produces around $9.45 \mathrm{Kcal}$ of net energy, while a typical carbohydrate generates around $4.4 \mathrm{Kcal}$. So, lipids, in general, provide 2.25 times more energy than traditional sources. Also, it is important to consider the intake of fatsoluble vitamins and essential fatty acids (Mayes, 1988).

Fats are part of a group of organic molecules called lipids, which accomplish many functions in the animal body: structural functions (part of cell membranes), hormonal functions (some hormones are of lipidic nature: estradiol, progesterone, testosterone, among others) and immunological functions. Some vitamins (A, D, E and K) are of lipid nature.

Fatty acids (FA) are fundamental molecules in the structure of a lipid, with hydrogenated carbon chains which contain an acidic or carboxyl group in one end and a methyl group in the other end (Jenkins, 2004). The length of the chains of the FA goes from 2 to 24 or more carbon atoms. It is common to name them according to the number of atoms and the number of double bonds, which serves to classify them as saturated or unsaturated fatty acids.

Animal tissues do not synthesized linoleic and linolenic acids (Omega 6 and Omega 3, respectively); they should therefore be incorporated within the diet (Jenkins, 2004). Both FA are known as essential in animal nutrition because they are required for many metabolic processes. Omega fatty acids belong to one of the three Omega families $(\omega): \omega-6, \omega-3$ and $\omega$ 9 (Table 1). Each family has a parental fatty acid, which can be converted into other biologically active acids within the same $\omega$ family (Jenkins, 2004). 


\begin{tabular}{lll}
\hline$\omega-$ Family & Parental fatty acid & Mayor Metabolite \\
\hline$\omega-9$ & $\begin{array}{l}\text { C 18:1 } \omega-9 ; \\
\text { Oleic acid }\end{array}$ & C 20:3 $\omega-9 ;$ Eicosatrienoic acid \\
\hline$\omega-6$ & $\begin{array}{l}\text { C 18: } 2 \omega-6 ; \\
\text { Linoleic acid }\end{array}$ & C 20:4 $\omega-6$, Arachidonic acid \\
\hline$\omega-3$ & C 18:3 $\omega-3 ;$ & C 20:5 $\omega-3$, Eicosapentaenoic acid \\
Linolenic acid & C 22:6 $\omega-3$, Docosahexaenoic acid \\
\hline
\end{tabular}

(Adapted from Jenkins, 2004.)

Table 1. Parental fatty acids and its main metabolites within each Omega family.

The sources of lipids in ruminant feeding systems are forages, cereals, oleaginous seeds, byproducts of the industry, such as the tallow, yellow fats, mixtures of vegetable and animal fats, hydrogenated fat, oil palm and calcium soaps. Tropical forages are relatively low in their content of lipids; the concentration of fatty acids in forages rarely exceeds $1.5 \%$ of the dry matter of the diet.

Both oils and fats, belong to the group of lipids, but differ in that the first are liquids at ambient temperature, while fats are solid. Another difference is that fats are usually from animal origin (tallow) while most of the oils are from vegetables (excluding fish oil). Fats have high levels of saturated fatty acids, while the oils contain more PUFA.

Fats and oils have limitations to be incorporated in the feeding of ruminants. It has been reported that levels $>5 \%$ of dry matter produced a decrease in food consumption of the animal. In this regards, Jenkins (1993) and Palmquist (1996) mention some of the possible ways of how fats can affect the microorganism action in the rumen:

- Rumen microorganisms cannot use the fiber because the formation of a film on the surface of the fiber, thus preventing the enzymatic and bacterial attack and disturbing the fermentation process.

- Reduction of microbial activity by adsorption of fat to the surface of the bacterial membrane.

- Possible formation of calcium and magnesium soaps in the rumen, which reduce the availability of essential minerals for the fermentative activity in the rumen.

- Elimination of a fraction of the microbial population due to possible toxic effects of some PUFA, especially on celulolitic bacteria.

The above generates a reduction in the ruminal microbial growth, which translates into a change in the production of volatile fatty acids in the rumen, with consequences to the acetic:propionic ratio and a decrease in the amount of acetic acid available for the production of fat in the mammary gland. In the particular case of unsaturated fatty acids, once they are free in the rumen, they suffer a massive hydrogenation process known as biohydrogenation (Jenkins, 1993), which consists in the addition of hydrogen atoms on the double bonds, thus transforming the unsaturated fatty acids into saturated fatty acids. Thus, PUFA as oleic (C18:1), linoleic $(\mathrm{C} 18, \omega-6)$ and linolenic acid $(\mathrm{C} 18, \omega-3)$, are transformed into 
the stearic FA (C18:0). Eicosapentaenoic acid (C20:5, $\omega-3)$ and docosahexaenoic acid (C22:6, $\omega-3)$ undergo very little hydrogenation in the rumen (Mattos et al., 2000). These two fatty acids are commonly found in oil and fishmeal.

When we use a source of fat, not protected or not a rumen-inert fat, with high levels of PUFA, most is lost due to the biohydrogenation, which is particularly important for PUFA $\omega-6$ and $\omega-3$, which are considered as essential in the diet and which have an important role on reproductive, immunological, metabolic and hormonal functions. Therefore, this type of susceptible fat to interact in the rumen, are known as active fat and its use is limited in ruminants.

New technologies have generated chemically modified fats that allow its use at higher levels and with a lower level ruminal interaction, which reduces the deleterious effects of lipids on the ruminal bacteria activity. This kind of fats is known as inert fat, by-pass fat, or protected fat. In this regard, Jenkins (2004) defines the inert greases as those fats that have been specifically designed to have very little, or no negative effect on the digestibility of foods in ruminants. Rumen-inert fats are often carboxylate calcium salts (calcium soaps), saturated fatty acids or hydrogenated fats.

The use of calcium soaps allows the incorporation of a higher level of unsaturated fatty acids in the diet of ruminants. This is particularly important in the case of essential fatty acids ( $\omega-6$ and $\omega-3)$ which not only provide an energy effect per se, but may have specific effects on the metabolism of tissues and organs (Staples et al., 1998). The melting point of rumen-inert fats, is usually above $100^{\circ} \mathrm{C}$ and solubility occurs at $\mathrm{pH}$ levels below 5.5 . These values of temperature and $\mathrm{pH}$ are present in the rumen, which allows the fat to by-pass the rumen. However, at the level of the abomasum and first portion of the duodenum $\mathrm{pH}$ levels are much lower, allowings the dissociation of the carboxylate salt, leaving the fatty acids available for absorption. Therefore, it can be concluded that supplementation of rumen-inert fats to ruminants generates an increase in the availability of unsaturated fatty acids at the intestinal level, and therefore may increase the absorption and their incorporation into tissues (Table 2).

\begin{tabular}{llll}
\hline Source of fat & Fat source fed & $\begin{array}{l}\text { Linoleic acid fed } \\
\text { ( }\end{array}$ & $\begin{array}{l}\text { Linoleic acid } \\
\text { appearing in small } \\
\text { intestine (g/day) })\end{array}$ \\
\hline Whole cottonseeds & 2.8 & 300 & 30 to 120 \\
Whole soybeans & 2.8 & 300 & 30 to 120 \\
Yellow grease & 0.45 & 77 & 8 to 31 \\
Tallow & 0.45 & 23 & 2 to 9 \\
Calcium soaps $(8,5 \% \omega-6)$ & 0.45 & 38 & 25 to 34 \\
\hline
\end{tabular}

(Adapted from Staples et al., 1998)

Table 2. Estimated amount of linoleic acid that reaches the small intestine in cows, depending on the source of fat. 


\section{Rumen-inert fat and the productive and reproductive responses in ruminants}

When the rumen-inert fat is included into the diet it incorporates more PUFA, which is not only an energy source, but also generates non-energetic benefits related to the impact of these FA on the metabolism, hormonal and immune responses. The energetic effect is related to the greater amount of energy that lipids have, which helps to reduce the NEB during the postpartum period, which translates into increased production of luteinizing (LH) and follicle-stimulating hormone (FSH) by the pituitary gland, generating more growth and follicular development and promoting the ovulation (Diaz et al., 2009).

Non-energetic effects are associated with the type of FA presents in the supplied fat, these effects are related with the increase in cholesterol (particularly the HDL fraction or "good cholesterol") levels, direct effects on ovaries and uterus, increase the levels of progesterone $\left(\mathrm{P}_{4}\right)$ and the modulation of the prostaglandins production (especially $\mathrm{PGF}_{2 \alpha}$ ). In addition, rumen-inert fat has direct effects on hormones and growth factors involved with the reproductive and productive activity (insulin, IGF-I, among others). Most of these non-energy effects are favored when PUFA ( $\omega-6$ and $\omega-3)$ are included in the diet. Figure 1 shows various of the non-energetic proposed mechanisms, that can generate this type of FA.

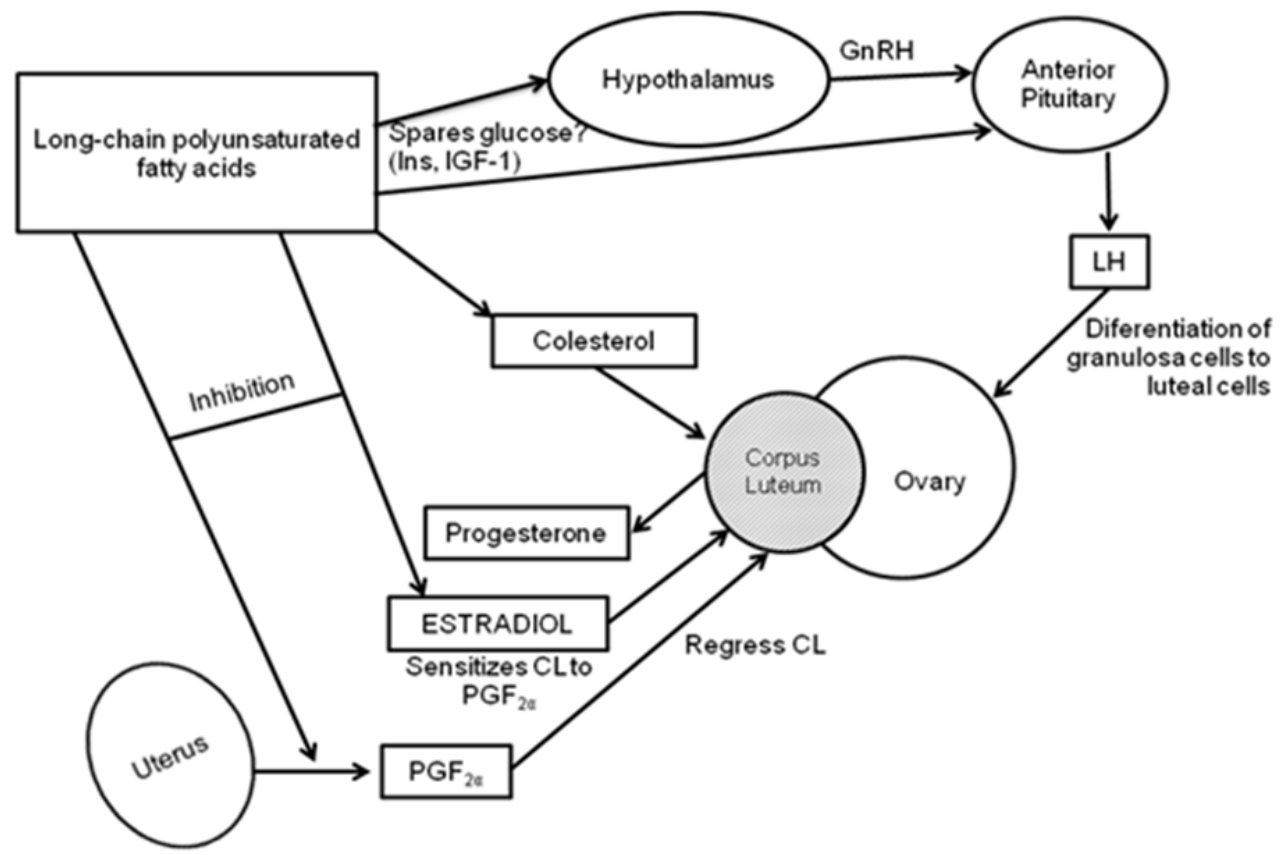

Figure 1. Proposed mechanisms of action by which PUFA supplementation can affect reproductive function. (Adapted from Staples et al., 1998). 
The impact of this type of fat is associated with the energy balance of the animal, particularly in the cow during early lactation, decreasing the deleterious effects of the NEB and improving the reproductive activity during the early postpartum. On this regard, Staples et al. (1998) mentioned that 11 out of 18 studies reviewing the effect of fat in cow's reproduction, reported an increase in reproductive performance, either because it improves the conception rate at first service or by increasing in the overall conception or pregnancy rates.

In addition, the supplementation with high levels of PUFA can generate a favorable response in milk production and composition, and an improvement in the fatty acid profile of the milk, particularly the levels of conjugated linoleic acid (CLA). Angulo et al. (2005) have described that some anticancer and antidiabetogenic properties of the CLA as well as the prevention of atheroma formation, the potentiation of the immune response and the improvement of bone mineralization. It may also increase levels of essential fatty acids $(\omega-6$ and $\omega-3$ ) in milk, which can cause the milk produced by cows or goats fed with this type of fat, would be a nutraceutical food.

\section{Experiences in Venezuela}

Experiences in Venezuela with the use of rumen-inert fat enriched with high levels of PUFA are promissory, either dairy and beef cattle, and small ruminants such as goats. Since 2007 the research group in the area of Nutrition - Reproduction interaction, in conjunction with researchers from the area of Animal Production at the College of Veterinary Sciences, Universidad Central de Venezuela, have been working on the effect of the rumen-inert fat enriched with high levels of polyunsaturated fatty acids on the productive and reproductive response in ruminants.

The research has been carried out in different ecological areas, with different types of production, levels of intensification, both in experimental stations and commercial farms, using the supplementation with rumen-inert fat given in different ways: multinutritional blocks (MNB); top-dress supplementation (fat placed on the concentrate supplement), in addition to the use of calcium soaps and mixed with mineral or concentrated supplement.

Regarding the effect of rumen-inert fat enriched with high levels of PUFA on the production of milk in a commercial trial, conducted with multiparous Carora breed cows, we evaluated the milk production during six months, obtaining a higher production per day and per lactation (20\% more) in cows supplemented with $400 \mathrm{~g}$ of rumen-inert fat enriched with high levels of PUFA (Energras ${ }^{\circledR}$ ) compared to cows in the control group. Results are shown in Table 3.

In crossbred Canary goats under tropical conditions, Salvador et al. (2009) evaluated the effect of by-pass fat supplementation ( $80 \mathrm{~g}$ Energras ${ }^{\circledR} /$ day) on milk production and composition. They reported a beneficial effect on the duration of lactation $(+44 \mathrm{~d})$, the milk production ( $+29.4 \%)$ and the content of milk components (41\% more fat, and $31.2 \%$ more protein), without altering the physical characteristic (WMT, acidity, $\mathrm{pH}$, cryoscopy) of the milk the supplemented goats (Table 4). 


\begin{tabular}{lcc}
\hline Parameters & $\begin{array}{c}\text { Treatment group } \\
(400 \text { g Energras }\end{array}$ & Contday) \\
\hline № animals & 8 & 8 \\
Liters/day & 13.8 & 11.7 \\
Total milk yield (Liters) & 16,852 & 14,055 \\
Diference (Liters/day) & $+2.1(17.9 \%)$ & \\
Diference in total milk yield (Liters) & $+2,797(19.9 \%)$ & \\
\hline
\end{tabular}

Otero (2007; unpublished data)

Table 3. Effect of supplementation with rumen-inert fat on milk production of Carora cows.

\begin{tabular}{lccc}
\hline Parameter & $\begin{array}{c}\text { Treatment group } \\
(80 \text { g Energras®/day) }\end{array}$ & Control group & Probability \\
\hline Milk yield (kg) & $274.4 \pm 18.5$ & $193.6 \pm 17.9$ & $* *$ \\
Days of milk & $272.6 \pm 15.9$ & $228.8 \pm 15.4$ & NS \\
Fat $(\mathrm{kg} / \mathrm{lactation})$ & $13.83 \pm 1.02$ & $8.16 \pm 1.05$ & $* *$ \\
Protein $(\mathrm{kg} / \mathrm{lactation})$ & $11.29 \pm 0.67$ & $7.76 \pm 0.69$ & $* *$ \\
Casein $(\mathrm{kg} / \mathrm{lactation})$ & $7.59 \pm 0.44$ & $5.19 \pm 0.46$ & $* *$ \\
Ashes $(\mathrm{kg} / \mathrm{lactation})$ & $2.12 \pm 0.14$ & $1.49 \pm 0.14$ & $* *$ \\
Lactose $(\mathrm{kg} / \mathrm{lactation})$ & $12.44 \pm 0.80$ & $8.99 \pm 0.83$ & $* *$ \\
Non fatty Solid (kg/lactation) & $25.86 \pm \pm 1.59$ & $18.25 \pm 1.65$ & $* *$ \\
Total solid (kg/lactation) & $39.70 \pm 2.56$ & $26.41 \pm 2.65$ & $* *$ \\
\hline
\end{tabular}

** $\mathrm{P}<0.01 ; \mathrm{NS}=$ not significant

(Adapted from Salvador et al., 2009)

Table 4. Effect of rumen-inert fat on milk production, days on lactation and composition of crossbred Canary goats

On the other hand, the milk lipid profile can be manipulated when supplementation with rumen-inert fat is given. Milk tends to have low levels of unsaturated fatty acids, being oleic acid (C18:1), a monounsaturated fatty acid, the most abundant (20\% approx.). The proportion of unsaturated fatty acids is less than the saturated ones. The formation of the milk fat may come from the novo synthesis fatty acids in the mammary gland or from the incorporation of fatty acids from the diet or body reserves. Regarding the long chain fatty acids (including $\omega-6$ and $\omega-3$ fatty acids) which are incorporated in the milk, about $40-45 \%$ come from the diet (Palmquist, 1996). Therefore, manipulating the diet by the incorporation of higher levels of fatty acids from rumen-inert fat, could be an strategy to change the milk fat composition in ruminants.

In recent years, the manipulation of milk fat content has taken great importance, with the aim of increasing the concentration of CLA in dairy products, which may contribute significantly to generate milk with nutraceutical properties of essential fatty acids that would contribute to the human health. In this regard, Zamora (2010), supplementing crossbred Canary goats with rumen-inert fat enriched with high levels of fatty acids (45 g/day ENERGRAS®), found significant differences $(\mathrm{P}<0.01)$ on oleic and linolenic acids 
concentrations between cheeses from treated and control goats: $(331.34 \pm 63.25$ vs. 28.02 $\pm 67.29 \mathrm{mg} / \mathrm{g}$ and $9.78 \pm 1,22$ vs. $5.41 \pm 1.30 \mathrm{mg} / \mathrm{g}$ respectively), when compared to the cheeses made from milk of goats supplemented (treatment vs. control) respectively. In addition, there was a trend in linoleic acid concentrations to be higher in chese from treated goats: (30.26 \pm 9.74 vs. $19.26 \pm 10.37 \mathrm{mg} / \mathrm{g}$ ), not affecting the quality and organoleptic properties of fresh cheeses (Table 5).

\begin{tabular}{|l|c|c|c|}
\hline VARIABLE & $\begin{array}{c}\text { Treatment group } \\
(80 \text { g Energras }(\mathbb{8} / \text { day })\end{array}$ & Control group & Probability \\
\hline Performance & & & \\
\hline Performance to 0 H & $3.9 \pm 0.1$ & $4.0 \pm 0.1$ & NS \\
\hline Performance to $48 \mathrm{H}$ & $4.8 \pm 0.1$ & $5.2 \pm 0.1$ & NS \\
\hline Characteristic: & & & \\
\hline Acidity & $13.1 \pm 1.7$ & $13.5 \pm 1.7$ & NS \\
\hline Clorures & $2.9 \pm 0.3$ & $2.9 \pm 0.3$ & NS \\
\hline pH & $5.6 \pm 0.1$ & $5.4 \pm 0.1$ & NS \\
\hline Components: & & & \\
\hline fat $(\%)$ & $24.5 \pm 1.2$ & $21.9 \pm 1.2$ & NS \\
\hline Protein $(\%)$ & $10.2 \pm 0.4$ & $10.7 \pm 0.4$ & NS \\
\hline Humidity $(\%)$ & $48.1 \pm 0.9$ & $48.4 \pm 0.9$ & NS \\
\hline Ash $(\%)$ & $4.3 \pm 0.2$ & $4.1 \pm 0.2$ & NS \\
\hline Solids $(\%)$ & $51.8 \pm 0.9$ & $51.5 \pm 0.9$ & NS \\
\hline Solids no fat $(\%)$ & $27.3 \pm 1.3$ & $29.6 \pm 1.3$ & NS \\
\hline Lactose $(\%)$ & $12.7 \pm 1.0$ & $14.6 \pm 1.0$ & NS \\
\hline Oleic C18:1 $(\mathrm{mg} / \mathrm{g})$ & $331.3 \pm 63.2$ & $28.0 \pm 67.2$ & $* *$ \\
\hline Linoleic C18:2 $(\omega-3)(\mathrm{mg} / \mathrm{g})$ & $30.2 \pm 9.7$ & $19.2 \pm 10.3$ & NS \\
\hline Linolenic C18:3 $(\omega-6)(\mathrm{mg} / \mathrm{g})$ & $9.7 \pm 1.2$ & $5.4 \pm 1.3$ & $*$ \\
\hline
\end{tabular}

NS: No significant; ${ }^{*} \mathrm{P}<0.05 ;{ }^{* *}: \mathrm{P}<0.01$ (Adapted from Zamora, 2010).

Table 5. Effect of rumen-inert fat on performance, characteristics and composition of fresh pasteurized goat's cheese.

In addition, the performance of milk in terms of kilograms of cheese showed no significant differences $(\mathrm{P}>0.05)$ between cheese made from milk of goats supplemented with rumeninert fat and cheese made from milk of goats without fat supplementation, (at $0 \mathrm{~h}$ and $48 \mathrm{~h}$ ), after the removal from the mould. Nevertheless, the cheeses made from milk of the treatment group needed less milk to produce $1 \mathrm{~kg}$ of fresh cheese $(140 \mathrm{~g}$ and $400 \mathrm{~g}$ less at 0 and 48 hours after the removal from the mould, respectively). At the moment of curd preparation there was not difference in terms of content of water retained ( $48.1 \%$ and $48.4 \%$ for treatment and control groups respectively). This could be due to, the protein content of 
the serum that could affect the production of cheese (cheese making performance and the drainage of whey, especially when milk from treated goats was heated; Raynal-Ljutovac et al., 2008). However, it is important to mention there were not statistical differences in terms of $\mathrm{kg}$ of cheese obtained from treated and control goats, the performance improved for processed cheese made from milk of goats that consumed rumen-inert fat, although they had a higher milk production, there were $47.95 \mathrm{~kg}$ of fresh cheese from the treated group and $25.37 \mathrm{~kg}$ of fresh cheese in the control group, with a difference of $47.09 \%$ for the treatment group.

It is important to mention that the rumen-inert fat did not affect the characteristics of the cheese, nor the chemical composition neither of its components, except FA, concentrations and minerals in the treatment group, which had a trend to be higher. Some additional results showed that the effect of the consumption of rumen-inert fat on the proportion of cis and trans FA found in fresh goat cheese, was not significant $(\mathrm{P}>0.05)$. However, the proportion was higher in milk from treated goats than in milk from control goats $(95.97 \pm$ 4.31 and $85.73 \pm 4.31$ respectively) which aggregates a value to the cheese, having a product with unsaturated cis FA, which has benefits to human health, because trans FA from of partially hydrogenated oils have been linked to deaths due to cardiovascular diseases (Giacopini, 2008).

Regarding to reproductive responses, the use of rumen-inert fat enriched with high levels of PUFA has been evaluated with promising results, particularly in first-calf Brahman cows in areas of well drained savannas in Cojedes States (Farms A and B) and Guárico States (Farm C) with acidic soils, in conditions of limited range and forage quality. In these studies Diaz et al. $(2008 ; 2009)$ used multinutritional blocks that were formulated with the aim of providing non protein nitrogen, rumen-inert protein, minerals (macro and microelements) and rumen-inert fat (with $17 \%$ of linoleic acid [ $\omega-6]$ ). In the case of Farm $A$, the breeding season was during the rainy season, while for the two other farms (B and C) breeding seasons ware during the dry period. Data of pregnancy rate are shown in Figure 2. Results showed higher pregnancy rates than those reported for the same type of animals under tropical conditions (30\%). Pregnancy rate for first calf Brahman cows in Farm A during the previous year was $46 \%$ much lower than the present results.

Diaz et al. (2009) and Hernandez (2010) also reported a beneficial effect of the supplementation with rumen-inert fat enriched with high levels of PUFA, during the postpartum period on ovarian activity of first-calf Brahman cows. Their results showed that supplementation with $150 \mathrm{~g}$ of $\mathrm{fat} / \mathrm{cow} / \mathrm{d}$ increased the accumulated number of Class 3 follicles $(\geq 10 \mathrm{~mm}$ ) during the first $90 \mathrm{~d}$ post-partum $(\mathrm{P}<0.06$; Figure 3$)$. In this regard Diaz (2009) suggested that a greater accumulated number of Class 3 follicles could be an indicator of a greater likelihood of having preovulatory follicles, so cows would have a greater chance of ovulation during the first $90 \mathrm{~d}$ postpartum. On the other hand, it is an indirect indicator of the onset of LH secretion after parturition, as this hormone is responsible for the final maturation of preovulatory follicles and subsequent ovulation. 


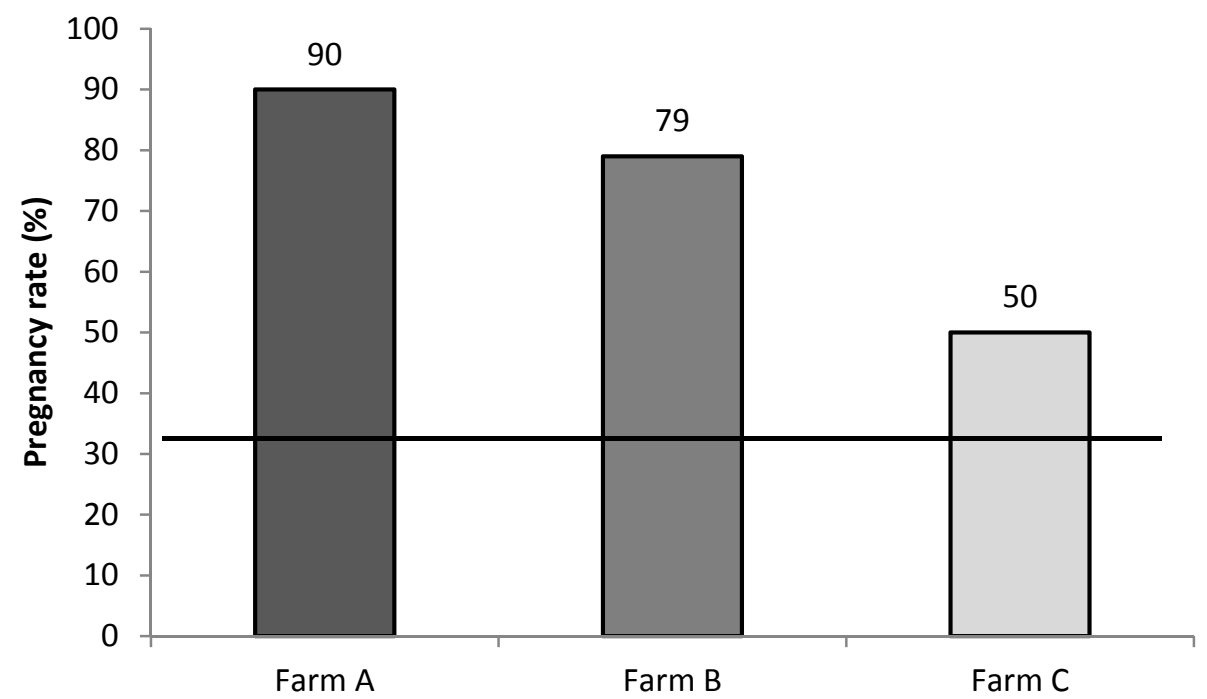

Figure 2. Pregnancy rate for first calf Brahman cows supplemented with multinutritional blocks enriched with rumen-inert fat. The line represents the pregnancy rate for first calf Brahman cows in Venezuela (Adapted from Diaz et al., 2008; 2009).

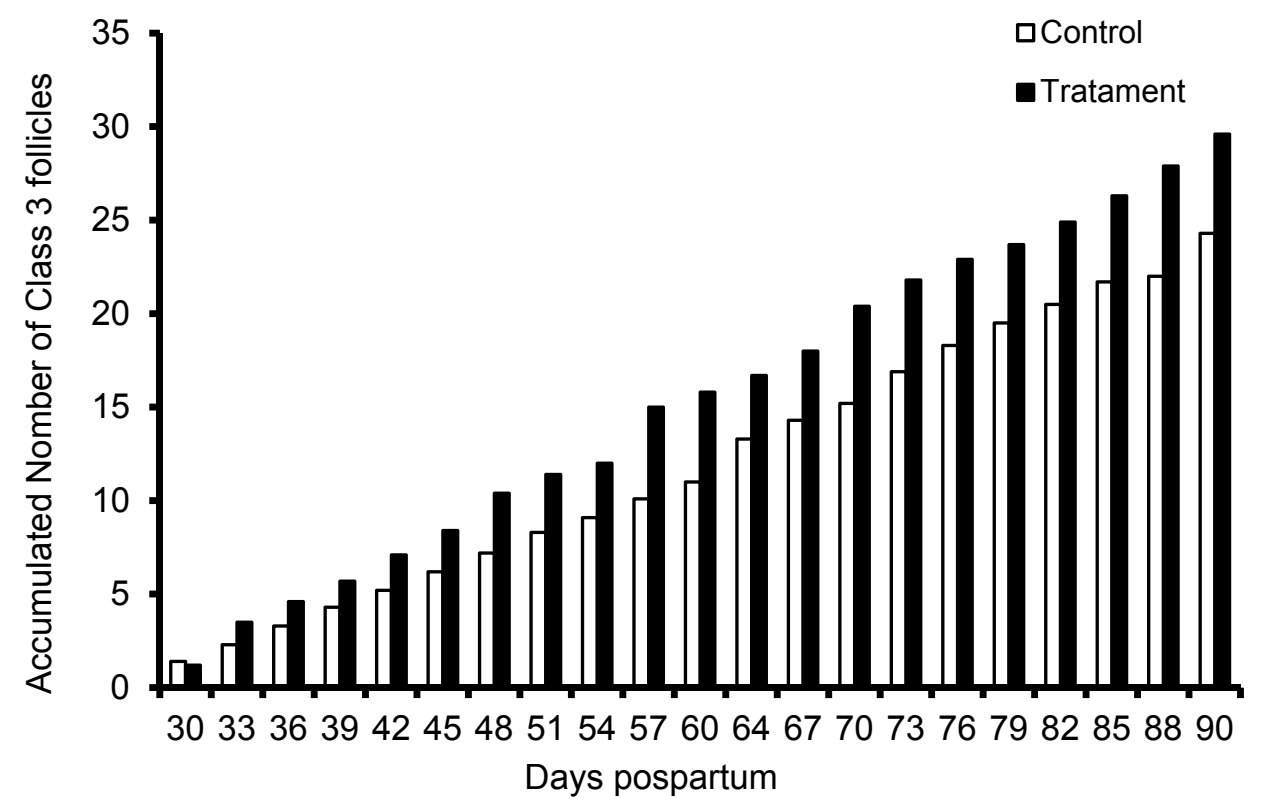

Figure 3. Accumulated number of Class 3 follicles $(\geq 10 \mathrm{~mm})$ between 30 and $90 \mathrm{~d}$ postpartum in firstcalf Brahman cows supplemented or non with-rumen-inert fat. 
Also, Hernandez (2010) reported that independent of significant difference in reproductive efficiency parameters between cows supplemented with rumen-inert fat and cows in the control group, there were numeric differences of 14 percentage points in conception rate, in favor of the supplemented cows (91\% vs. $77 \%$ ) and $12 \mathrm{~d}$ shorter interval from calving to conception (days open: 90 vs. $102 \mathrm{~d}$ in treatment and control group respectively). Those numbers would translate into an increase in reproductive efficiency and therefore the profitability herd.

In another experiment (cows received $250 \mathrm{~g}$ of rumen-inert fat/cow/d) we found a $20 \%$ reduction in the interval between calving and first estrus (control cows: $98 \mathrm{~d} v \mathrm{~s} .78 \mathrm{~d}$ in supplemented cows). In this case the fat used as a supplement contained $5 \% \omega-3$ and $17 \% \omega-$ 6, (Unpublished data). It is important to note that the cows supplemented with $\omega-6$ presented problems of consumption at the beginning of the trial.

Diaz et al. (2009) considered that the $\omega-6$ fatty acids should be provided to stimulate cyclic ovarian activity early in the post-partum, while the $\omega-3$ fatty acid (linolenic acid, DHA and EPA) should be supplied during early pregnancy. In this regard, several authors (Petit et al., 2002;) Mattos et al., 2003) indicate that $\omega-6$ fatty acids stimulate synthesis of $\mathrm{PGF}_{2 \alpha}$, as well as $\omega-3$ stimulates the synthesis of series 3 prostaglandins, which can block the synthesis of the former, specifically the $\mathrm{PGF}_{2 \alpha}$ by competitive inhibition of enzymes that regulate their synthesis.

However, there are contrasting evidences regarding the role of the $\omega-6$ fatty acids and the synthesis of $\mathrm{PGF}_{2 \alpha}$. To this respect, Staples et al. (2002), indicate that linoleic acid has inhibitory effects both in vitro and in vivo, probably dose related, as the excess of this fatty acid might reduce the synthesis of prostaglandins in series 1 and 2 (i.e., PGF2a). These same authors point out, that the inhibition may be due to a competitive effect with arachidonic acid by the prostaglandin endoperoxide synthase enzyme (PGSH). Therefore, a rich source of $\omega-6$ fatty acids could reduce the synthesis of PGF $2 \alpha$, prolonging the lifespan of the corpus luteum, allowing the implantation of the embryo and decreasing the early embryonic mortality.

On the other hand, Diaz et al. (2009) argue that both the maintenance of pregnancy, and the onset of postpartum ovarian activity may occur with the single supply of linoleic acid. Therefore, the use of rumen-inert fat enriched with high levels of $\omega-6$ and/or $\omega-3$ could contribute positively on uterine involution, the resumption of postpartum ovarian activity and reduction of days open in beef and dairy cows.

\section{Effect of rumen-inert fat supplementation on the voluntary consumption}

Salvador et al. (2009) reported that there were not significant differences between groups in terms of voluntary consumption of food. Both groups consumed the whole dose of concentrate ( $200 \mathrm{~g}$ with $18 \%$ of crude protein) across the lactation period. Also, there were 
no differences $(\mathrm{P}>0.05)$ in terms of consumption of hay of Bermuda grass (Cynodon dactylon) offered ad libitum between groups $(0.85 \pm 0.02 \mathrm{~kg}$ and $0.83 \pm 0.02 \mathrm{~kg}$ for treatment and control group respectively). These results are consistent with those reported by Teh et al. (1994), González and Bas (2002) and Sanz Sampelayo et al. (2002a).

Figure 4 shows that there was a significant effect $(P<0.05)$ of days in milk on the consumption of hay, showing that hay consumption increased immediately after the peak of lactation and decreased as the milk production reduces, coinciding with results reported by Jimeno et al. (2003) who pointes out that the lowest level of consumption is just one week before calving. On the other hand, the voluntary consumption increased after calving up to the maximum consumption between 6 to 10 weeks; However, it was not linear increase. Then, subsequent to the peak of milk the consumption declined linearly as the milk production decreased.

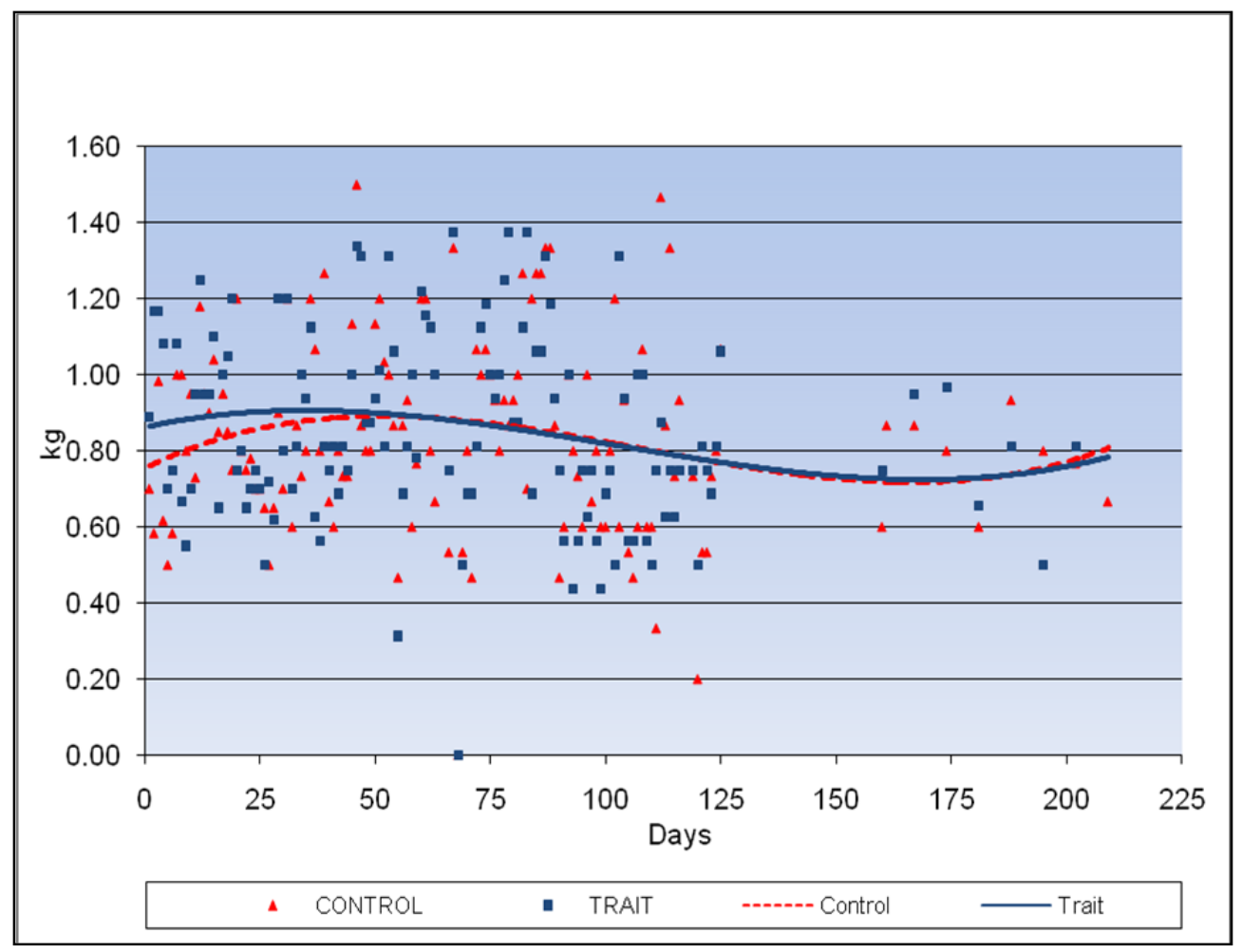

Figure 4. Effect of rumen-inert fat on the voluntary consumption of hay in crossbreed Canarian goats during lactation. 
Regarding to the consumption of the of rumen-inert fat $(80 \mathrm{~g})$ by goats in the treated group, there was no rejection of the fat, consuming all the by-pass offered.

Results showed that the addition of this type of rumen-inert fat has no a substitute effect of the main component of the diet of ruminants (grass) but works as a supplement, thereby improving the quality of the diet, reducing the NEB, and improving the productive and reproductive parameters.

\section{Final considerations}

Supplementation with rumen-inert fat enriched with high levels of PUFA, should start enough time before parturition, to promote energy reserves of the animal (to improve body condition score) and to maintain body condition during the early postpartum period, in order to reduce the negative effects that has NEB on the production and reproduction in ruminants. Diaz et al. (2009) recommend that this type of fat supplementation, should begin between 21-40 days before calving, with doses between 100 and $400 \mathrm{~g} / \mathrm{cow} /$ day, according to the type of cow (dairy or dual purpose cows). The time that the supplementation will be given varies according to the farm, the basal diet, the level of production, the type of animal, etc., but in general it is recommended to keep it during 90 days postpartum, period in which requirements of the cows are higher because they reach the peak of milk production.

Salvador et al. (2009) y Zamora (2010) recommend in dairy goats, that supplementation with this type of fat, would be given during the same way and time but with lower levels (45 and $80 \mathrm{~g} / \mathrm{goat} / \mathrm{d}$ ) depending on the weight and the level of production of the goat.

Although the rumen-inert fat is not the solution to all problems of our farms, it is a food resource of great potential, that contains high levels of polyunsaturated fatty acids that allows the incorporation of beneficial effects that essential, fatty acids ( $\omega-6$ and $\omega-3)$ may have on the reproductive and productive activity of our herds and at the same time generating meat, milk and other derivatives with better nutritional quality.

\section{Author details}

Alejandro Salvador

Unidad Experimental de Producción Caprina,

Facultad de Ciencias Veterinarias, Universidad Central de Venezuela, Maracay, Venezuela

Rolando Hernandez

Cátedra de Nutrición Animal,

Facultad de Ciencias Veterinarias, Universidad Central de Venezuela, Maracay, Venezuela

Thais Diaz

Instituto de Reproducción Animal "Dr. Abraham Hernandez Prado", Facultad de Ciencias Veterinarias, Universidad Central de Venezuela, Maracay, Venezuela 
Ricardo Betancourt

Cátedra de Nutrición Animal,

Facultad de Ciencias Veterinarias, Universidad Central de Venezuela, Maracay, Venezuela

\section{References}

Angulo, J., Machecha, L., Giraldo, C. and Olivera M. 2005. Prostaglandinas y grasa de la leche: síntesis a partir de ácidos grasos poliinsaturados, en bovinos. In: M. Pabón y J. Ossa (Eds.) Bioquímica, Nutrición y Alimentación de la Vaca. Fondo Editorial Biogénesis. pp. 111-135. Medellín, Colombia.

Bach A. 2003. La reproducción del vacuno lechero: nutrición y fisiología. VII Curso de Especialización FEDNA La reproducción del vacuno lechero: nutrición y fisiología. Purina, España. In: http://www.etsia.upm.es/fedna/capitulos/2001CAPV.pdf

Diaz T. 2009. Aspectos de la fisiología reproductiva de la hembra Brahman. Trabajo de ascenso. Facultad de Ciencias Veterinarias, Universidad Central de Venezuela. pp. 93.

Diaz, T., Betancourt, R., Hernandez, R. and Gallo, J. 2009. El efecto de las grasas omega 3 y omega 6 sobre la reproducción de vacas de primera lactancia pastoreando en los llanos venezolanos. In: E. Chacón y F. Espinoza (Eds). Memorias III Simposium Sobre Recursos y Tecnologías Alimentarias Apropiadas para la Producción Bovina a Pastoreo en Condiciones Tropicales. Pasteurizadora Táchira C.A. (PASTCA). San Cristóbal. Pp. 1-28 CD-ROM.

Diaz, T., Betancourt, R., Hernandez, R., Romero, C., Gallo, J. and Cardona, M. 2008. Effects of by-pass fat feeding on the reproductive performance of first-calf Brahman cows under tropical Savannah conditions. Reproduction in Domestic Animals. 43:37. (Abstr.).

Giacopini, M. 2008. Efecto de los ácidos grasos trans sobre las lipoproteínas del plasma. Archivos Venezolanos de Farmacología y Terapéutica. 27(1): 19-21.

González F., and Bas, F. 2002. Efecto de la suplementación con un aceite hidrogenado de pescado sobre la producción de leche en vacas Holstein Friesan. Cien. Invest. Agrop. 29(2): 73-82.

Hernandez, R. 2010. Efectos de la suplementación con grasa sobrepasante sobre parámetros productivos y reproductivos en vacas Brahman de primer parto a pastoreo. Trabajo de ascenso. Facultad de Ciencias Veterinarias, Universidad Central de Venezuela. pp. 97.

Jenkins T. 2004. Challenges of meeting cow demands for omega fatty acids. Florida Ruminant Nutrition Symposium. In:

http://dairy.ifas.ufl.edu/files/rns/2004/Jenkins.pdf

Jenkins T. 1993. Lipid metabolism in the rumen. Journal of Animal Science. 76: 38513863. 
Jimeno V., Rebollar, P., and Castro, T. 2003. Nutrición y alimentación del caprino de leche en sistemas intensivos de explotación. XIX Curso de Especialización FEDNA. Madrid, España.

Mattos, R., Guzeloglu, A., Badinga, L., Staples C. R., and Thatcher. W. W. 2003. Polyunsaturated fatty acids and bovine interferon- $\tau$ modify phorbol ester-induced secretion of prostaglandin F2a and expression of prostaglandin endoperoxide synthase2 and phospholipase-A2 in bovine endometrial cells. Biology of Reproduction. 69: 780787.

Mattos R., Staples C.R. and W.W. Thatcher. 2000. Effects of dietary fatty acids on reproduction in ruminants. Reviews of Reproduction. 5:38-45.

Mayes P.A. 1988. Lípidos de importancia fisiológica. En: Bioquímica de Harper. 11ª Ed, Editorial Manual Moderno, México, D.F. Pp. 129-141.

Montaño E.L. and Ruiz Z.T. 2005. ¿Por qué no ovulan los primeros folículos dominantes de las vacas cebú posparto en el trópico colombiano? Rev Col Cienc Pec Vol 18:2 127135

Palmquist DL. 1996. Utilización de lípidos en dietas de rumiantes. En: http:// www.etsia.upm.es/fedna/capitulos/96capituloIII.pdf

Petit H., R. Dewhurst, N. Scollan, J. Prolux, M. Khalid, W. Haresing, H. Twagiramungu and G. Mann. 2002. Milk production and composition, ovarian function, and prostaglandin secretion of dairy cows fed omega 3 fats. Journal of Dairy Science. 85:889-899.

Raynal-Ljutovaca, K., Lagriffoul, K., Paccard, G., Guillet, and P., Chilliard. 2008. Composition of goat and sheep milk products: An update. Rev. ScienceDirect. Small Ruminant Research. 79 : 57-72.

Salvador A., Alvarado C., Contreras I., Betancourt R., Gallo J. and A. Caigua. 2009. Efecto de la alimentación con grasa sobrepasante sobre la producción y composición de la leche de cabra en condiciones tropicales. Zoot. Trop. 27:285-298.

Sanz Sampelayo M., Martin, J., Pérez, L., Gil, F., and Boza, J. 2002. Effects of concentrates with different content of protected fat rich in PUFAs on the performance lactating Granadina Goats. 1. Feed intake, nutrient digestibility, $\mathrm{N}$ and energy utilization for milk production. Small Rum. Res., 43(3): 133-139.

Staples C., R. Mattos, S. Boken, L. Sollenberger, W. W. Thatcher and T. Jenkins. 2002. Feeding fatty acids for fertility? Proceedings of the $13^{\text {th }}$ Annual Florida Ruminant Nutrition Symposium. Pp 71-85. En:

http://dairy.ifas.ufl.edu/rns/2002/staples.pdf

Staples C.R., J.M. Burke and W.W. Thatcher. 1998. Influence of supplemental fats on reproductive tissues and performance of lactating cows. Journal of Dairy Science. 81:856-871.

Teh T., Trung, L., Jia, Z., and Gipson, T. 1994. Varying amounts of rumen-inert fat for high producing goats in early lactation. J. Dairy Sci., 77: 253-258. 
Zamora R. 2010. Producción y composición de la leche y queso fresco pasteurizado de cabras suplementadas con grasa sobrepasante con altos niveles de ácidos grasos poliinsaturados. Tesis de grado para obtener el título de Ingeniero Agrónomo. Facultad de Agronomía. UCV. Maracay, Venezuela. 